\title{
Factor III Measurement
}

National Cancer Institute

\section{Source}

National Cancer Institute. Factor III Measurement. NCI Thesaurus. Code C81959.

The determination of the amount of factor III present in a sample. 